\title{
AGENT OF CHAOS? OR A REFLECTION OF AMERICAN SOCIETY? THE TRUTH BEHIND GOTHAM'S GREATEST CRIMINAL
}

\section{CHELSEA SMITH}

It is difficult to see comic books as anything other than entertainment, or to see them as historical sources. In all honesty, it is easy to see why comics are designed for entertainment, the 'good' guy always wins, the 'bad' guy is defeated, and nothing has to follow logic. Heroes pull off impossible stunts, and villains somehow cause an unimaginable amount of damage, often with fantastic tools that would be difficult to make or obtain. However, it can be argued that Batman's Joker has more purpose than to simply be defeated by Batman. As this paper argues, Joker represents and reflects the fears of American society, throughout the 20th and 21st centuries. As the fears of each decade have changed and evolved, so has Joker, to match the darkest anxieties of the time. If Batman is the hero that Gotham and small children need then Joker is the boogeyman, designed to represent whatever the current fear is, and to demonstrate that fears can be conquered.

Using Batman comics, as well as Detective Comics and Joker's own comic books from 1939 to the present day, it will be demonstrated how significantly Joker has changed. Versions of Joker that have appeared in television shows and movies will also be examined, as they provide equal insight into the character, and allow him more means of expression. This paper will demonstrate the changes in Joker chronologically, and will compare these changes to the historical period that they occurred in.

The story of the Joker begins with the worst stock market crash that modern history has ever known, Black Tuesday, which occurred on October 29th, 1929. This crash, combined with tariffs placed on exported goods, a drought, bank failures, and reluctance from consumers to 
purchase items, all lead to what we know as the Great Depression. Mass unemployment spread through the nation, as people competed for work that employers simply could not afford to pay them for anymore. People went hungry, and often became homeless. There was a trend of leaving one's family, with the belief that there might be jobs elsewhere. Organized crime had already been a struggle for law enforcement to control during the 1920's prohibition era, but now the gangsters posed a different threat. Alcohol that the gangsters provided became a comfort, as people feared what would happen to their money. However, gangs would also rob banks and steal the money of the already poor, leaving them in a worse condition than they had previously been. ${ }^{1}$ Gangsters were on the rise - at one point there was an estimated 1300 gangs in Chicago alone $^{2}$ - and some had become well known. Criminals such as Al Capone, John Dillinger, George Nelson, and Bonnie and Clyde had made names for themselves as bank robbers, thieves and murderers. The former had henchmen to do their bidding, to the point where gangsters had their own small armies. ${ }^{3}$ What had certainly not helped in this case was media involvement - gangsters and gang violence was easy to discuss in the news, due to its action and excitement. The drama had functioned as a real-life action movie, complete with guns, shootouts, money stolen from banks, and police attempts to stop the individual gangsters - not to mention gangsters escaping from jail or having been set free in an exchange. These gangsters were turned into characters,

\footnotetext{
${ }^{1}$ Thomas Emerson Hall and J. David Ferguson, The Great Depression: an international disaster of perverse economic policies (Ann Arbor, MI: Univ. of Michigan Press, 2001).

2 "The FBI and the American Gangster, 1924-1938," FBI. May 03, 2016. https://www.fbi.gov/history/briefhistory/the-fbi-and-the-american-gangster (accessed March 09, 2019).

3 “American History: The Great Depression: Gangsters and G-Men," John Jay College of Criminal Justice, CUNY. March 5, 2019 https://guides.lib.jjay.cuny.edu/c.php?g=288390\&p=1922564 (accessed March 09, 2019).
} 
each with favourite nicknames and mannerisms, as stories of what each one did spread throughout the country as fast as the media could report it. ${ }^{4}$

Joker came into existence in 1939, in Detective Comics \#27. He was a gangster in his first appearance, with a small gang of loyal minions to boss around. His goal was simple; rob banks, and become wealthy. ${ }^{5}$ This Joker was not afraid to kill people in order to get what he wanted, relying on his gang members to carry out the bank robberies, and willfully shooting anyone who objected or stood in his way. He was a familiar character to the citizens, as a representative of the organized crime of both Prohibition and the Great Depression. He was doing the scariest thing that one can do - he stole money and left poor people even poorer. He targeted the population where it hurt the most - their wallets. As a member of an organized crime group, it did not matter if he was defeated- he had other people to continue to steal money. Like gangsters and mobsters before him, Joker had the power to get what he wanted, and had the ability to rule over both his gang and the police, if he so chose.

The 1950's played a large role in creating its social customs. The social anxiety of the 1950s was not conflict from other populations, but was instead conflict from the younger generation. The aftermath of the Second World War left those who had returned from the War, those who did not go, and the small population of teenagers in a suddenly prosperous country that had many jobs to be filled. ${ }^{6}$ The older generation, who were done with fighting and violence, or too used to military standards, had tried to enforce this straight-laced style on the teenagers.

\footnotetext{
4 "Dillinger was famous for having escaped from jail twice, one time carving a bar of soap to look like a gun." "American History".

${ }^{5}$ Bill Finger, "Detective Comics," Comic strip in Detective Comics \#27. Vol. 27. (New York: DC Comics, 1939).

6 "Since there are fewer of them, each — in the most prosperous time in U.S. history - gets a bigger piece of the nation's economic pie than any previous generation ever got," Nina Leen, "The Luckiest Generation," LIFE, June 14, 1954.
} 
However, with the economy of the time going so well, and with so few teenagers around, many teens were able to make their own money, and, consequently, their own decisions. Many teenagers rebelled against the rules set for them, creating their own culture, as well as a fear of teen delinquency. ${ }^{7}$ Teenagers were free to buy their own clothes, listen to their own music, and decide what was 'cool' and 'popular'. Teenagers had acted out their rebellion throughout the decade in anyway they could, metaphorically laughing at authority as they wore their baggy jeans and listened to loud music being sung by a man who wiggled his hips in front of all of America.

Through the 50s and 60s, Joker turns over a new leaf, becoming an annoying prankster instead of a killer. The Comic Code Authority, matching the straight laced style of the 50s, insisted that comics were much too violent. As a result, Joker stops using guns, and begins using hand buzzers and practical jokes. He gets a prankster utility belt in order to help him escape from Batman. ${ }^{8}$ However, this does not mean that this Joker is not reflective of cultural anxiety. Joker acts as a force of rebellion against the norms of the time. His purpose is to question, laugh at, and challenge authority, just as the teenagers do. He does not follow rules, choosing instead to make a laughing stock out of anyone who tries to assimilate him. Joker also rebels against the ruling of the Comic Code Authority, by not using weapons, but for implying a great deal of violence. Cesar Romero's Television and Movie Joker uses incredible gadgets to start conflict, and his fists to stop Batman. Violence is only implied through the swinging of fists, and the sudden

\footnotetext{
${ }^{7}$ One part of this new teenage culture was reflective of the clothing they chose to wear- choosing baggy jeans and motorcycle boots over button-down shirts, ties and khakis, or modest skirts. William Graebner, "The 'Containment' of Juvenile Delinquency: Social Engineering and American Youth Culture in the Postwar Era," Mid-America American Studies Association 27, no. 1 (1986): 81-97. Retrieved from https://journals.ku.edu/amerstud/article/view/2537 (accessed March 10, 2018).

${ }^{8}$ Bill Finger, "Batman," comic strip, in Batman \#66, vol. 66 (New York, NY: DC Comics, 1951).
} 
appearance of an onomatopoeia ${ }^{9}$ to cover the screen. ${ }^{10}$ While the audience does not actually see a character become injured, they see the build up to it, and the strong implication of it, thus not technically breaking the Comic Code's ruling, yet still demonstrating violence in the closest manner possible.

1974 was marked by the questioning of personal responsibility, as role models were found doing horrible things. Two cases occurred at the time that caused debates over what justice was, and what to do with the offender: the Watergate scandal, and the Patricia Hearst Case. Nineteen-year-old Patricia Hearst was kidnapped in her home by the Symbionese Liberation Army. She was locked in a closet for days, until she was successfully "brainwashed". She joined the Liberation Army, and changed her name to Tania, becoming a vocal member. She helped rob banks, kidnapped a man, sent her parents ransom notes and made bombs in order to kill police officers. ${ }^{11}$ She may have been successfully portrayed by her lawyer as a person acting under duress, had it not been for the testimonies of Eden Shea, a bank security guard, and Thomas Matthews, a high school student that Hearst had helped kidnap, which confirmed her complacency. ${ }^{12}$ Her case sparked much discussion; was she an innocent victim of a kidnapping, merely going along to stay alive, or must she face jail time for the crimes that she had helped commit? Would it be justice to simply let her walk away, or would justice for the victims be

\footnotetext{
${ }^{9}$ Such as "Boom", "Oomph", "Crack" or "Pow"

${ }^{10}$ Batman. dir. Leslie H. Martinson. perf. by Adam West. United States: 20th Century Fox, 1966. Film; William Dozier, writer, Batman, ABC, January 12, 1966.

11 "Patty Hearst," FBI, May 18, 2016, accessed March 7, 2018, https://www.fbi.gov/history/famous-cases/pattyhearst.

${ }^{12}$ In his testimony, Shea had claimed that he had seen Hearst, and that she had been a willing participant in the robbery of the bank he had worked at. "She said a few things. Amongst them, she said: 'First person that puts up his head, I'll blow his mother-fucking head off'... then I went ahead of the area to go lay down on the floor." "Testimony of Eden Shea in the Patty Hearst Trial," Famous Trials, 1995 http://famous-trials.com/pattyhearst/2214sheatestimony (accessed March 13, 2018).
} 
achieved with her jail time? After much controversy, Patricia Hearst was sentenced to 35 years in jail, later reduced to 7 , of which she served 2 before being pardoned. ${ }^{13}$

On June 19, 1972, President Nixon and his administration had covered up a situation where five people had broken into the Democratic National Committee headquarters in the Watergate office complex. After the five men were arrested, the truth was exposed, leading to an investigation of Watergate. The investigation revealed that the Nixon administration had been abusing their power, bugging offices of those they were suspicious of, and had used the FBI and CIA to investigate political groups. This political scandal led to the impeachment of President Nixon. ${ }^{14}$ However, it was not without controversy. Nixon had been elected to be the President of the United States. While some were horrified by what he had done, he was still their elected official, and his job was to work in the best interest of the people. The President was the last person anyone would have suspected to commit such a serious scandal, and yet he did. This brings up the question; if the president is the most important person in the United States, who is above them to punish them for their wrongdoings?

Joker, following the theme of personal responsibility, gets his own comic book in 1975 . For once, he is the hero of the story. Although the comic only lasted nine issues, every issue ends with Joker being arrested for his crimes. This hero, the teller of the story and the character that the reader depends upon, must take responsibility for what he has done and face the consequences. In the first issue, The Joker's Double Jeopardy, Joker gets offended when he is not invited to a bank robbery, and breaks out in order to disrupt the villains' plans. Joker

\footnotetext{
13 "Patty Hearst," FBI, May 18, 2016, https://www.fbi.gov/history/famous-cases/patty-hearst (accessed March 7, 2018).

${ }^{14}$ Keith W. Olson and Max Holland, Watergate: the presidential scandal that shook America (Lawrence, KS: University Press of Kansas, 2016).
} 
manages to capture the villain, and they beat each other up until the police arrive. While Joker is the hero, and he does manage to save the day, he is arrested for his actions. ${ }^{15}$ Being 'a good person' and a hero is not enough to save him from facing the consequences of his crimes. Nixon was his own sort of hero; as the President, he had a lot of power, and his job was to make the United States a better place. Hearst was a fairly average 19-year-old girl, who was kidnapped. Both committed a few 'bad' actions- abusing power, and joining a terrorist group- just like Joker did when he broke out of jail. Like Joker, both are punished for their actions, although there is a feeling of doubt when it comes to if and how they should be punished.

The 1980s presented what appeared to be a period of defeated morale in the United States, with a series of mishaps, mistakes, tragedies and murders that dominated newspaper headlines. The murder of John Lennon on December 8th, 1980 by Mark David Chapman resulted in public unrest. ${ }^{16}$ It was a senseless death, by someone who had asked for Lennon's autograph merely hours before ${ }^{17}$ His murder was foretelling of what was to be expected. Following this was a failed hostage negotiation in 1981, where 52 Americans were being held hostage in Iran. Diplomatic negotiations and rescue attempts had failed, and the people were only freed when Iraq invaded Iran. ${ }^{18}$ The morale crushing events continued, with the Bhopal disaster of 1984 , which was the World's worst industrial disaster until $2010 .{ }^{19}$ Nineteen eighty-five had a famine

\footnotetext{
${ }^{15}$ Denny O'Neil, “The Joker's Double Jeopardy,” DC Comics, 1975.

${ }^{16}$ Harriet Alexander, "John Lennon's killer revealed details of shooting as he was denied parole for the ninth time," The Telegraph, September 16, 2016, https://www.telegraph.co.uk/news/2016/09/16/john-lennons-killer-revealeddetails-of-shooting-as-he-was-denie/ (accessed March 10, 2018).

17 "The assassination was an abrupt coda to an age still in search of itself. When he shot John Lennon, Chapman robbed us all of an opportunity to better understand ourselves." Jack Jones, Let me take you down: inside the mind of Mark David Chapman, the man who shot John Lennon (London: Virgin, 2001): 2.

${ }^{18}$ David Farber, Taken hostage: the Iran hostage crisis and America's first encounter with radical Islam (Princeton, NJ: Princeton University Press, 2005).

${ }^{19}$ Ming Yang, Faisal Khan, and Paul Amyotte, "Operational risk assessment: A case of the Bhopal disaster," Process Safety and Environmental Protection 97 (2015) doi:10.1016/j.psep.2015.06.001 (accessed March 6, 2018).
} 
in Africa, which the United States had desperately attempted to raise funds for with the song $W e$ Are The World. ${ }^{20}$ The space shuttle Challenger exploded in 1986, on a televised broadcast that the horrified public watched. ${ }^{21}$ Individuals lost a lot of money in the stock crash of 1987, referred to as Black Monday. ${ }^{22}$ Terrorism and disasters appeared to be on the rise, appearing on newspaper headlines and taking up conversations.

In this context, Joker becomes less interested in robbing banks or killing random civilians: his attack becomes more focused and personalized in ways that echo the wider social fixations - he is a terrorist. In the 1988 comic entitled A Killing Joke, Joker shoots Batgirl in the stomach - hitting her spine and paralyzing her - while attempting to kidnap her father to demonstrate to Batman that anyone can be morally compromised. Joker beats and psychologically tortures the Commissioner, with Batman unable to stop him. ${ }^{23}$ Joker is also successful in killing the second Robin, Jason Todd, in the 1988 comic A Death in the Family. Joker captures and beats Jason with a crowbar, and kills both Jason and his mother with a time bomb. ${ }^{24}$

Batgirl, Robin and Commissioner Gordon are all specifically hunted down and injured, or killed, by Joker, in scenarios where Batman is helpless to save them. He is too late to save Robin, has no idea that Batgirl was a target, and could not find the Commissioner on his own. Joker hurts Batman by targeting very specific people in his life and ruining him psychologically to the

\footnotetext{
${ }^{20}$ Frances D'souza and Jeremy Shoham, "The spread of famine in Africa: Avoiding the worst," Third World Quarterly 7, no. 3 (1985) doi:10.1080/01436598508419852 (accessed March 6, 2018)..

${ }^{21}$ Sue L. Hamilton and John Hamilton, Space shuttle: Challenger, January 28, 1986 (Bloomington, MN: Abdo \& Daughters, 1988).

${ }^{22}$ Black Monday, the stock market crash of October 19, 1987: hearings ... One Hundredth Congress, second session, on the turbulence in the financial markets ... February 2, 3, 4 and 5, 1988. Washington: U.S. G.P.O., 1988.

${ }^{23}$ Alan Moore et al., Batman: the killing joke (New York: DC Comics, 1988).

${ }^{24}$ Jim Starlin, Jim Aparo, and Mike DeCarlo, Batman: A Death in the Family (New York, NY: DC Comics, 1988).
} 
point where he swears to never have another Robin, and declares that he cannot bear to bury another member of the Bat family.

What is also noteworthy is that Joker is given a backstory in A Killing Joke. He is shown to be a normal man, who, for the most part, is very relatable. A failed comedian who is desperate to support his beloved pregnant wife, agrees to guide two criminals through a chemical plant that he used to work at. His wife dies in what is reported to be a household accident, but Joker is forced to go through with the plan. Both criminals are killed in a shootout, and Joker jumps into a vat of chemicals to avoid Batman, which physically changes him. ${ }^{25}$ It is his emotional torment that turns him into a killer. Forever changed by this tragic string of events, Joker relentlessly subjects Batman to unimaginable pain and anguish. The terrorist who caused so much damage was once a normal man, embracing anger after a string of tragedy.

This fear of individual terrorism continues into the 2000s, with Heath Ledger's Joker in The Dark Knight becoming the ultimate terrorist. ${ }^{26}$ He blows up banks and hospitals, taking delight in forcing innocent people to make life and death decisions regarding other people. ${ }^{27} \mathrm{He}$ is not interested in money; he burns billions of dollars as a means of sending a message. ${ }^{28} \mathrm{He}$ also manages to twist the mind of a 'good' person, demonstrating how simple it was. District Attorney Harvey Dent has to watch as his city falls into chaos, as Joker kills people and plants

\footnotetext{
${ }^{25}$ Alan Moore et al., Batman: the killing joke (New York: DC Comics, 1988).

${ }^{26}$ The Dark Knight, dir. Christopher Nolan, prod. Emma Thomas and Charles Roven, perf. Christian Bale and Heath Ledger (United States: Warner Bros. Entertainment, Inc., 2008), film.

${ }^{27} \mathrm{He}$ does this four times in the movie. Once, when he dresses up hostages as henchmen, and dares the police to shoot them. He also fills two cruise ships with people, giving them the ability to blow up the other ship, as well as a promise that he will blow up both ships if both are still floating within an hour. He kidnaps a couple, placing them in separate locations with time bombs, and only allows batman enough time to save one, forcing him to pick. Finally, Joker also puts a loaded gun in the hands of Harvey Dent, while holding his forehead against the muzzle and daring him to shoot.

28 'I'll show ya. When the chips are down, these uhh, these civilized people, they'll eat each other". The Dark Knight, dir. Christopher Nolan, prod. Emma Thomas and Charles Roven, perf. Christian Bale and Heath Ledger (United States: Warner Bros. Entertainment, Inc., 2008), film.
} 
explosives. He and his fiancée Rachel are kidnapped and are told that only one of them will survive, and it is up to Batman to decide who will be saved. Dent is forced to listen as the woman he loves dies, as Batman arrives at his location. The emotional torment from this turns him into the villain Two Face; a good man who turned into a terrorist rather easily. This is the fear; that one small person, with a defeated morale, facing their own emotional torment, will lash out and cause well-targeted pain and suffering in others. From 1980 onward, there was a long series of public tragedies, resulting in low morale, as well as millions of people who could suddenly snap. ${ }^{29}$ Mark David Chapman was previously a normal man. Iran was not a serious threat before. Torment had twisted the mind of one character into a killer- how many other minds could it twist, and how many more morale-crushing events would it take until people gave up hope?

Nineteen ninety-two was an important year for Joker, as this is when his girlfriend, Harley Quinn, was introduced into the comics. She is madly in love with him, devoting her life to Joker and happily going along with his schemes, even if it involves pain and suffering on her end. Joker, however, makes it clear that he is not interested in Harley as a person, as she is badly mistreated. In Batman; the Animated Series, he repays her loyalty and love by throwing her out of windows, pushing her off of a desk when she wants attention, and setting hyenas on her ${ }^{30}$ In the comics, he treats her similarly. He promises to marry her so that he can sacrifice her to a volcano, ${ }^{31}$ chains her up with similarly dressed corpses and reminds her that she can be

\footnotetext{
${ }^{29}$ No one fears the monster outside; instead, we fear the monster under our beds. The threat is not external, but rather internal, laying in the hands of individuals. Thus, it is the individuals, and their potential to do so much harm, that is the anxiety. A terrorist always starts as a normal person.

${ }^{30}$ Batman; the animated series- Mad Love, by Bruce Timm and Paul Dini, perf. Kevin Conroy and Mathew Valencia (United States, 1994), television show.

${ }^{31}$ Amanda Conner and Jimmy Palmiotti, "Harley Quinn: Futures End," comic strip, ed. Bobbie Chase, in Harley Quinn: Futures End (New York, NY: DC Comics, 2014).
} 
replaced. ${ }^{32} \mathrm{He}$ fails to notice when she leaves for a year to give birth to his daughter, ${ }^{33}$ and throws her out of a window when she takes it upon herself to kill Batman. ${ }^{34}$ When Joker wants to cut her face off, her main concern is not that she is about to literally lose her face - but that he will not think that she is beautiful anymore. To calm these fears, he assures her that he never did: “Oh, Harley! When did I ever say I found you beautiful?”. ${ }^{35}$ Every attempt at love on her part is met by physical and psychological injury. Harley is trapped in this abusive relationship. She lives with Joker, and is financially supported by him. He is the father of her child. She depends upon him emotionally, as he is the only one who understands what happened to her and why she acts the way she does. When they had met, she was desperate and lonely for a companion - she was his physiatrist, and had fallen in love with him because of how he had listened to her, and was able to make her laugh. ${ }^{36}$ The final thing binding her to Joker is that they are both criminals; the police are not about to arrest Joker for throwing Harley out of a window, without also arresting Harley for her role in the crimes that the pair have committed together. Joker is all she has, and she is not in a position to leave him. Every time she had attempted to leave - or to kill him - it always resulted in her returning to him, more in love than ever.

Third Wave Feminism took over in the 90s, fighting for further social rights for women. Specifically, they were fighting for reproductive rights and access to birth control, ${ }^{37}$ the end of violence against women in both the public and domestic sense, and the end of derogatory terms.

\footnotetext{
32 Ales Kot et al., Suicide Squad, 14 vols. (New York: DC Comics, 2014).

33 Tom Taylor et al., Injustice: Gods among us year two (New York: DC Comics, 2014).

${ }^{34}$ Paul Dini and Bruce Timm, "The Batman Adventures- Mad Love," comic strip, in The Batman Adventures- Mad Love, vol. 1 (DC Comics, 1994).

35 James Tynion, "Batman \#13," comic strip, in Batman \#13, 13th ed., vol. 2 (New York, NY: DC Comics, 2012).

${ }^{36}$ Paul Dini and Bruce Timm, "The Batman Adventures- Mad Love," comic strip, in The Batman Adventures- Mad Love, vol. 1 (DC Comics, 1994).

${ }^{37}$ Including abortion, interestingly enough. The goal was to allow each woman to choose whether or not she wanted children, and if she wanted to abort the child, so be it.
} 
As Susan Faludi claims in her study on the topic, the 80's self-help books, which were targeted at women, endorsed being obedient to their men. The American Psychiatric Association had considered the emotional outbursts that went with Premenstrual Symptom to be a mental disorder, dismissing women as crazy. ${ }^{38}$ Third Wave feminists fought to change the ideas around women, to the point where a wife is an equal partner to her husband, and had succeeded. In 1994, the Violence Against Women Act was legislated, in order to bring justice for victims of domestic violence, violence by a romantic partner, stalking and sexual assault. ${ }^{39}$ This means that the fear of the time, at least from a feminist standpoint, was a man who behaved exactly like Joker. Joker is the embodiment of the worst type of man, in his treatment of Harley Quinn. He does everything they are fighting against; he beats her, makes fun of her, and limits her reproductive rights when it comes to their child. He is not there for her, or their daughter. He drags her deeper into the violence, threatening her life multiple times, and there is nothing she can do.

The current Joker, following the modern fears, actually has two different Jokers to represent two completely different, but not invalid, fears. The first Joker is the 2016 Suicide Squad's Joker. Although he only appeared briefly, it is his actions that speak volumes. This Joker represents a failure of mental health. When he is introduced by the film, it is as Dr. Harleen Quinzel's mental patient. Through flashbacks, one can see many forms of therapy, including electroconvulsive therapy. ${ }^{40}$ However, as the rest of the movie demonstrates, their sessions have not helped Joker in any way. When Joker breaks out, he prepares to administer electroconvulsive

\footnotetext{
38 Susan Faludi, Backlash: The Undeclared War against American Women (New York: Three Rivers Press, 1991).

${ }^{39}$ National Research Council, staff, Nancy A. Crowell, and Ann Wolbert. Burgess, Understanding Violence Against Women (Washington: National Academies Press, 1996).

${ }^{40}$ Suicide squad, dir. David Ayer, prod. Charles Roven and Richard Suckle, perf. Will Smith, Jared Leto, Margot Robbie, Joel Kinnamen and Viola Davis, Suicide Squad, August 1, 2016, accessed March 7, 2018.
} 
therapy to Dr. Quinzel. He tells her, with confidence, that it will hurt, "really, really bad." 41 The next thing one notices is that Joker appears to be lacking memory, as if something is wrong with his brain. He confirms this, with an outburst of "You helped me by erasing my mind, and what memories I had! Now, you left me in a black hole of rage and confusion." ${ }^{42}$ Harley is the final reflection of mental health; one might do crazy things for love, but becoming a psychotic killer is not one of them. It is her attempts to cure Joker's mental health that make him worse, and then she, an educated and healthy women, endures the same treatments and becomes just as bad, if not worse, than him.

This is the age of mental health. There has been a $400 \%$ increase of people taking antidepressants since 1988, and more mental conditions have been recognized since then. ${ }^{43}$ This may seem like a good thing, as more people are getting help, yet it has also caused critics to question the validity of mental health treatments. First and foremost, these are medications made by companies, to be sold to consumers. The fear is that the push of unnecessary mental health treatments to "cure" otherwise normal human behaviour is costing the consumer money, as well as causing damage to the user. While $400 \%$ more people are taking antidepressants, how many of them actually need it? What could it be doing to their brains? As mental health is studied further and more attempts are made to understand it, there still remain questions on how, exactly, to fix it. When it comes to physical ailments, there are treatments and cures that are known to work. A broken bone or cuts have fairly standard treatments that work on most people. Mental health is far more challenging to identify, and every person is unique, meaning that the same

\footnotetext{
${ }^{41}$ Suicide squad.

${ }^{42}$ Suicide squad.

${ }^{43}$ Peter Wehrwein, "Astounding increase in antidepressant use by Americans," Harvard Health, October 20, 2011, https://www.health.harvard.edu/blog/astounding-increase-in-antidepressant-use-by-americans-201110203624 accessed March 11, 2018.
} 
approaches to a cure do not work on everyone. While antidepressants, for example, may work on those who are depressed, it can take many attempts to find the best antidepressant to suit the individual's needs. However, as Perrin's 2012 studies have shown, the same antidepressants will cause a reduced connectivity in the person's brain. The study goes on to compare antidepressants to a more extreme form of treating depression and other mental illnesses - electroconvulsive therapy. The results reported a similar reduced connectivity in the brain. ${ }^{44}$ The side effects of this therapy include temporary memory loss, headaches, jaw pain, muscle pain, and less of an emotional reaction to memories. It is unknown how or why electroconvulsive therapy works, and there is a stigma of brutality to it, making it the last case scenario to attempt to fix the problems of the mind.

The second modern Joker is from the lesser known 2015 animated film Batman Unlimited; Monster Mayhem. This Joker takes an entirely new approach from that of Joker's past. He has a computer virus made and distributed to all of Gotham, which plunges the city into total darkness as Joker controls every electronic device. He declares himself 'King Joker,' and uses infected electronics, and robotic hero Cyborg, to battle Batman.

In the current society, computers are king. This will be demonstrated by discussing hacking on a personal level, on a corporate level, and finally how simple hacking truly is. As technology becomes smarter, and capable of interconnecting to do tasks, many more security risks have been created. As James Veitch has summed up in a TED talk, "The internet gave us access to everything, but it also gave everything access to us." ${ }^{45}$ While people might be aware

\footnotetext{
${ }^{44}$ Jennifer Perrin et al., "Electroconvulsive therapy reduces frontal cortical connectivity in severe depressive disorder," Yearbook of Psychiatry and Applied Mental Health, March 19, 2012, doi:10.1016/j.ypsy.2012.06.003.

${ }^{45}$ YouTube, September 27, 2016, https://www.youtube.com/watch?v=Dceyy0cX6J4\&t=305s (accessed March 08, 2018).
} 
that their cell phones and computers can be hacked, and certainly go out of their way to protect them, there are other methods that hackers can use to get into computers. ${ }^{46}$

On a personal level, the average home and office are becoming 'smarter,' with light bulbs, thermostat, cars, credit cards and locks to doors connected to a cell phone, for convenience. In a hacking method called 'Pivoting,' one does not go after the highly secured device, but instead after a much less protected device on the same network and travels the network from that device onto the computer. ${ }^{47}$ American hackers Charlie Miller and Chris Valasek have demonstrated how easily they can hack into a car's computer system and take over, completely taking away acceleration and brakes from the driver. ${ }^{48}$ There are also reports of baby monitors being hacked into, only noticed when unknown voices started talking to children. ${ }^{49}$ Most cell phones have a GPS system in them, and a camera. With apps like Snapchat and Facebook, the apps are getting better at recognizing faces through snapchat filters and Facebook tagging. Furthermore, cell phones and smart houses have microphones that are designed to allow the person to talk to the device and verbally input commands. This means that, not only is this

\footnotetext{
${ }^{46}$ Richard Barber, "Hacking Techniques: The tools that hackers use, and how they are evolving to become more sophisticated," ScienceDirect 2001, no. 3 (March 23, 2001): doi:10.1016/S1361-3723(01)03014-7.

${ }^{47}$ Natalie Dobbin, "Why hackers might be drawn to your smart light bulbs," CBC news, November 22, 2016, http://www.cbc.ca/news/canada/nova-scotia/smart-light-bulbs-hacking-1.3836516 (accessed March 08, 2018).

${ }^{48}$ Andy Greenberg, "Hackers Remotely Kill a Jeep on the Highway-With Me in It," Wired, June 03, 2017, accessed March 08, 2018, https://www.wired.com/2015/07/hackers-remotely-kill-jeep-highway/. This test occured in St. Louis, with a willing participant, to demonstrate what influence a hacker could have on a car. From ten miles away, the hacker pair turned up the air conditioning, changed the radio station, started the windshield wipers, and took control of the accelerator, letting the Jeep slowly roll to a stop on a Highway. "As I frantically pressed the pedal and watched the RPMs climb, the Jeep lost half its speed, then slowed to a crawl." (Greenburg)

${ }^{49}$ Chenda Ngak, "Baby monitor hacked, spies on Texas child," CBS News, August 13, 2013, https://www.cbsnews.com/news/baby-monitor-hacked-spies-on-texas-child/ (accessed March 8, 2018). In 2013, a report of a man's voice came through a baby monitor in Texas, where "the hacker used the device to curse and say sexually explicit things to the sleeping girl -- calling her by name and telling her to wake up." (Ngak) It is unknown who the Hacker was, or how long he had been watching the two-year-old. In 2014, a similar report came from Ohio, of an unknown man screaming at a baby girl from a baby monitor in the infant's room, as well as complaints that the camera would pan around the room on its' own.
} 
piece of technology listening to one's voice, but it understands what one is saying. On March 7, 2018, Amazon received complaints of their Smart home device, Alexa, laughing unprompted, scaring users, and indirectly confirming that Alexa is always listening. ${ }^{50}$

On a wider scale, hacking has the power to destroy society. One of the most famous examples of destructive public hacking occurred in Afghanistan in 2008. A member of the United States Military found a USB, which infected military computers with a worm, sending all of the computer's information off to the unknown hacker. ${ }^{51}$ Another example of this is Stuxnet in 2010, which was a computer virus that targeted the control systems of the Iranian Nuclear Program. It was designed to give the machines different commands, while outwardly displaying normal functions. Each subroutine had a very specific purpose. "One, known as a man in the middle, caused tiny adjustments in the pressure inside the centrifuges. Another manipulated the speed of the centrifuges' spinning rotors... destabilizing the rotors and ruining their work. On top of this, the malware would occasionally push the centrifuge speeds past the designed maximum...the machines literally spun out of control and exploded". 52

\footnotetext{
50 "In rare circumstances, Alexa can mistakenly hear the phrase 'Alexa, laugh.' We are changing that phrase to be 'Alexa, can you laugh?' which is less likely to have false positives." Rachel Sandler, "Amazon says the laughing Echo devices that terrified some users happened because Alexa 'mistakenly' thought it heard instructions to laugh," Business Insider, March 07, 2018, http://www.businessinsider.com/amazon-confirms-echo-devices-laughingworking-fix-2018-3 (accessed March 10, 2018).

51 "Defense officials would not describe the extent of damage inflicted on military networks. But they said that the attack struck hard at networks within U.S. Central Command, the headquarters that oversees U.S. involvement in Iraq and Afghanistan, and affected computers in combat zones. The attack also penetrated at least one highly protected classified network." Julian E. Barnes, "Cyber-attack on Defense Department computers raises concerns," Online posting, November 8, 2008, Los Angeles Times, http://www.latimes.com/news/nationworld/iraq/complete/lana-cyberattack28- 2008nov28,0,230046.story (accessed March 7, 2018).

${ }^{52}$ P. W. Singer, "Stuxnet And Its Hidden Lessons On the Ethics Of Cyber weapons," Case Western Reserve Journal of International Law 47, no. 3 (March 1, 2015) doi:108307851 (accessed March 8, 2018).
} 
Hacking is not only for the elite. One can easily find step-by-step tutorials on how to pivot-hack a system. ${ }^{53}$ Hacking has gone from something only the brightest criminal can do, to a thing that a bored teenager can accomplish in a short amount of time. In 2012, a 15-year-old Austrian boy spent three months hacking into 259 different companies, using codes that he had found online. ${ }^{54}$ In 2014, two 14-year-old boys used their lunch break to hack into an ATM machine, after finding a manual of how to do so online. ${ }^{55}$

Joker's evolution has taken many different turns, as he has become Gotham's greatest criminal. What makes him the best is his ability to be unpredictable - always changing - and his ability to scare the public. He is a mirror for society, showing us the worst parts about ourselves, creatively reminding us that our fears are very real and very dangerous. He is the embodiment of anxiety, which is what makes him a successful villain. The storyline is the same; Joker reminds us of our anxieties, and Batman temporarily beats him down, until a new anxiety is formed.

\footnotetext{
${ }^{53}$ Sathyajith Sathyabalan et al., "Hack Like a Pro: How to Pivot from the Victim System to Own Every Computer on the Network," WonderHowTo, January 20, 2014, https://null-byte.wonderhowto.com/how-to/hack-like-propivot-from-victim-system-own-every-computer-network-0149847/ (accessed March 08, 2018).

${ }^{54}$ Melanie Hick, "15-Year-Old Arrested For Hacking 259 Companies," HuffPost UK, April 18, 2012, http://www.huffingtonpost.co.uk/2012/04/18/15-year-old-arrested-for-hacking-259-companies_n_1433494.html (accessed March 08, 2018).

${ }^{55}$ Doug Lunney, "Code-cracking teens hack into Grant Avenue ATM," Winnipeg Sun, June 8, 2014, http://winnipegsun.com/2014/06/08/code-crackers--charleswood-teens-hack-into-grant-avenue-atm/wcm/6685e1db8f09-4dfa-94fe-de80bb32e925 (accessed March 8, 2018).
} 


\section{Bibliography}

Alexander, Harriet. "John Lennon's killer revealed details of shooting as he was denied parole for the ninth time." The Telegraph. September 16, 2016. Accessed March 10, 2018. https://www.telegraph.co.uk/news/2016/09/16/john-lennons-killer-revealed-details-ofshooting-as-he-was-denie/.

Barber, Richard. "Hacking Techniques: The tools that hackers use, and how they are evolving to become more sophisticated." ScienceDirect 2001, no. 3 (March 23, 2001).

Barnes, Julian E. "Cyber-attack on Defense Department computers raises concerns." Online posting. November 8, 2008. Los Angeles Times. Accessed March 7, 2018. http://www.latimes.com/news/nationworld/iraq/complete/la-na-cyberattack282008nov28,0,230046.story.

Batman. Directed by Leslie H. Martinson. Performed by Adam West. United States: 20th Century Fox, 1966. Film.

Batman; the animated series- Mad Love. By Bruce Timm and Paul Dini. Performed by Kevin Conroy and Mathew Valencia. United States, 1994. Television Show.

Black Monday, the stock market crash of October 19, 1987: hearings ... One Hundredth Congress, second session, on the turbulence in the financial markets ... February 2, 3, 4 and 5, 1988. Washington: U.S. G.P.O., 1988.

Conner, Amanda, and Jimmy Palmiotti. "Harley Quinn: Futures End." Comic strip. Edited by Bobbie Chase. In Harley Quinn: Futures End. New York, NY: DC Comics, 2014.

Dini, Paul , and Bruce Timm. "The Batman Adventures- Mad Love." Comic strip. In The Batman Adventures- Mad Love. Vol. 1. DC Comics, 1994.

Dobbin, Natalie. "Why hackers might be drawn to your smart light bulbs." CBC news. November 22, 2016. Accessed March 08, 2018. http://www.cbc.ca/news/canada/novascotia/smart-light-bulbs-hacking-1.3836516.

Dozier, William. Writer. Batman. ABC. January 12, 1966.

Dsouza, Frances, and Jeremy Shoham. "The spread of famine in Africa: Avoiding the worst." Third World Quarterly 7, no. 3 (1985): 515-31. Accessed March 6, $2018 .$.

Faludi, Susan. Backlash: the undeclared war against American women. New York: Three Rivers Press, 1991.

Farber, David. Taken hostage: the Iran hostage crisis and America's first encounter with radical Islam. Princeton, NJ: Princeton University Press, 2005. 
Finger, Bill. "Batman." Comic strip. In Batman \#66. Vol. 66. New York, NY: DC Comics, 1951.

Finger, Bill. "Detective Comics." Comic strip. In Detective Comics \#27. Vol. 27. New York, NY: DC Comics, 1939.

Graebner, William. "The 'containment' of juvenile delinquency: social engineering and American youth culture in the postwar era." Mid-America American Studies Association 27, no. 1 (1986). Accessed March 10, 2018.

Greenberg, Andy. "Hackers Remotely Kill a Jeep on the Highway-With Me in It." Wired. June 03, 2017. Accessed March 08, 2018. https://www.wired.com/2015/07/hackers-remotelykill-jeep-highway/.

Hall, Thomas Emerson, and J. David Ferguson. The Great Depression: an international disaster of perverse economic policies. Ann Arbor, MI: Univ. of Michigan Press, 2001.

Hamilton, Sue L., and John Hamilton. Space shuttle: Challenger, January 28, 1986. Bloomington, MN: Abdo \& Daughters, 1988.

Hick, Melanie. "15-Year-Old Arrested For Hacking 259 Companies." HuffPost UK. April 18, 2012. Accessed March 08, 2018. http://www.huffingtonpost.co.uk/2012/04/18/15-yearold-arrested-for-hacking-259-companies_n_1433494.html.

Jones, Jack. Let me take you down: inside the mind of Mark David Chapman, the man who shot John Lennon. London: Virgin, 2001.

Kot, Ales, Matt Kindt, Patrick Zircher, Andy Owens, Derek Fridolfs, Marc Deering, Sami Basri, Keith Champagne, Carmen Carnero, Bit, and Jason Pearson. Suicide Squad. 14 vols. New York: DC Comics, 2014.

Leen, Nina. "The Luckiest Generation." LIFE, June 14, 1954.

"LibGuides: American History: The Great Depression: Gangsters and G-Men." Home American History: The Revolutionary War - LibGuides at John Jay College of Criminal Justice, CUNY. March 5, 2019. Accessed March 09, 2019. https://guides.lib.jjay.cuny.edu/c.php?g=288390\&p=1922564.

Lunney, Doug. "Code-cracking teens hack into Grant Avenue ATM." Winnipeg Sun, June 8, 2014. Accessed March 8, 2018. http://winnipegsun.com/2014/06/08/code-crackers-charleswood-teens-hack-into-grant-avenue-atm/wcm/6685e1db-8f09-4dfa-94fede80bb32e925.

Moore, Alan, Brian Bolland, John Higgins, and Richard Starkings. Batman: the killing joke. New York: DC Comics, 1988. 
Ngak, Chenda. "Baby monitor hacked, spies on Texas child." CBS News, August 13, 2013. Accessed March 8, 2018. https://www.cbsnews.com/news/baby-monitor-hacked-spieson-texas-child/.

Olson, Keith W., and Max Holland. Watergate: the presidential scandal that shook America. Lawrence, KS: University Press of Kansas, 2016.

O'Neil, Denny. “The Joker’s Double Jeopardy.” DC Comics, 1975.

"Patty Hearst." FBI. May 18, 2016. Accessed March 7, 2018. https://www.fbi.gov/history/famous-cases/patty-hearst.

Perrin, Jennifer, Susanne Merz, Daniel Bennett, James Currie, Douglas Steele, Christian Schwarzbauer, and Ian Reid. "Electroconvulsive therapy reduces frontal cortical connectivity in severe depressive disorder." Yearbook of Psychiatry and Applied Mental Health, March 19, 2012.

"Research Starters: Worldwide Deaths in World War II." The National WWII Museum | New Orleans. Accessed March 11, 2018. https://www.nationalww2museum.org/studentsteachers/student-resources/research-starters/research-starters-worldwide-deaths-worldwar.

Sandler, Rachel. "Amazon says the laughing Echo devices that terrified some users happened because Alexa 'mistakenly' thought it heard instructions to laugh." Business Insider. March 07, 2018. Accessed March 10, 2018. http://www.businessinsider.com/amazonconfirms-echo-devices-laughing-working-fix-2018-3.

Sathyabalan, Sathyajith, Angie Adams, Ghadeer Alali, and Nop Yep. "Hack Like a Pro: How to Pivot from the Victim System to Own Every Computer on the Network." WonderHowTo. January 20, 2014. Accessed March 08, 2018. https://null-byte.wonderhowto.com/howto/hack-like-pro-pivot-from-victim-system-own-every-computer-network-0149847/.

Singer, P. W. "Stuxnet And Its Hidden Lessons On the Ethics Of Cyber weapons." Case Western Reserve Journal of International Law 47, no. 3 (March 1, 2015). Accessed March 8, 2018.

Staff, National Research Council., Nancy A. Crowell, and Ann Wolbert. Burgess. Understanding Violence Against Women. Washington: National Academies Press, 1996.

Starlin, Jim, Jim Aparo, and Mike DeCarlo. Batman: A Death in the Family. New York, NY: DC Comics, 1988.

Suicide Squad. Directed by David Ayer. Produced by Charles Roven and Richard Suckle. Performed by Will Smith, Jared Leto, Margot Robbie, Joel Kinnamen and Viola Davis. Suicide Squad. August 1, 2016. Accessed March 7, 2018. 
Taylor, Tom, Bruno Redondo, Julien Hugonnard-Bert, Mike S. Miller, and Saleem Crawford. Injustice: Gods among us year two. New York: DC Comics, 2014.

"Testimony of Eden Shea in the Patty Hearst Trial." Famous Trials. 1995. Accessed March 13, 2018. http://famous-trials.com/pattyhearst/2214-sheatestimony.

The Dark Knight. Directed by Christopher Nolan. Produced by Emma Thomas and Charles Roven. Performed by Christian Bale and Heath Ledger. United States: Warner Bros. Entertainment, Inc., 2008. Film.

"The FBI and the American Gangster, 1924-1938." FBI. May 03, 2016. Accessed March 09, 2019. https://www.fbi.gov/history/brief-history/the-fbi-and-the-american-gangster.

Tynion, James. "Batman \#13." Comic strip. In Batman \#13. 13th ed. Vol. 2. New York, NY: DC Comics, 2012.

YouTube. September 27, 2016. Accessed March 08, 2018. https://www.youtube.com/watch?v=Dceyy0cX6J4\&t=305s.

Wehrwein, Peter. "Astounding increase in antidepressant use by Americans." Harvard Health, October 20, 2011. Accessed March 11, 2018. https://www.health.harvard.edu/blog/astounding-increase-in-antidepressant-use-byamericans-201110203624.

Yang, Ming, Faisal Khan, and Paul Amyotte. "Operational risk assessment: A case of the Bhopal disaster." Process Safety and Environmental Protection 97 (2015): 70-79. Accessed March 6, 2018. 